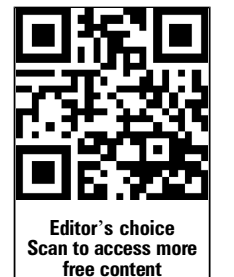

free content

\title{
Guidelines for surveillance of individuals with constitutional mismatch repair-deficiency proposed by the European Consortium "Care for CMMR-D" (C4CMMR-D)
}

\author{
H F A Vasen, ${ }^{1,2}$ Z Ghorbanoghli, ${ }^{2}$ F Bourdeaut, ${ }^{3}$ O Cabaret, ${ }^{4}$ O Caron, ${ }^{5}$ A Duval, ${ }_{1}^{6}$ \\ N Entz-Werle, ${ }^{7}$ Y Goldberg, ${ }^{8}$ D llencikova ${ }_{1}^{9}$ C P Kratz, ${ }^{10} \mathrm{~N}$ Lavoine, ${ }^{11} \mathrm{~J}$ Loeffen, ${ }^{12}$ \\ F H Menko, ${ }^{13}$ M Muleris, ${ }^{6} \mathrm{G}$ Sebille, ${ }^{14} \mathrm{C}$ Colas, $^{15,6}{ }^{15}$ Burkhardt, ${ }^{16}$ L Brugieres, $^{11}$ \\ $\mathrm{K}$ Wimmer, ${ }^{17}$ on behalf of the EU-Consortium Care for CMMR-D (C4CMMR-D)
}

For numbered affiliations see end of article.

\section{Correspondence to} Professor Dr HFA Vasen, Department of Gastroenterology \& Hepatology, Leiden University Medical Centre,

Rijnsburgerweg 10, Leiden 2333 AA, The Netherlands; hfavasen@stoet.nl

Received 19 December 2013 Revised 7 January 2014 Accepted 20 January 2014 Published Online First 20 February 2014
To cite: Vasen HFA, Ghorbanoghli Z, Bourdeaut $F$, et al. J Med Genet 2014;51:283-293.

\section{ABSTRACT}

Lynch syndrome (LS) is an autosomal dominant disorder caused by a defect in one of the DNA mismatch repair genes: MLH1, MSH2, MSH6 and PMS2. In the last 15 years, an increasing number of patients have been described with biallelic mismatch repair gene mutations causing a syndrome referred to as 'constitutional mismatch repair-deficiency' (CMMR-D). The spectrum of cancers observed in this syndrome differs from that found in LS, as about half develop brain tumours, around half develop digestive tract cancers and a third develop haematological malignancies. Brain tumours and haematological malignancies are mainly diagnosed in the first decade of life, and colorectal cancer (CRC) and small bowel cancer in the second and third decades of life. Surveillance for CRC in patients with LS is very effective. Therefore, an important question is whether surveillance for the most common CMMR-D-associated cancers will also be effective. Recently, a new European consortium was established with the aim of improving care for patients with CMMR-D. At a workshop of this group held in Paris in June 2013, one of the issues addressed was the development of surveillance guidelines. In 1968, criteria were proposed by WHO that should be met prior to the implementation of screening programmes. These criteria were used to assess surveillance in CMMR-D. The evaluation showed that surveillance for CRC is the only part of the programme that largely complies with the WHO criteria. The values of all other suggested screening protocols are unknown. In particular, it is questionable whether surveillance for haematological malignancies improves the already favourable outcome for patients with these tumours. Based on the available knowledge and the discussions at the workshop, the European consortium proposed a surveillance protocol. Prospective collection of all results of the surveillance is needed to evaluate the effectiveness of the programme.

\section{INTRODUCTION}

Lynch syndrome (LS) is an autosomal dominant disorder caused by a heterozygous defect in one of the DNA mismatch repair (MMR) genes, that is, MLH1, MSH2 (and EPCAM deletion-mediated MSH2 methylation), MSH6 or PMS2. Carriers of a MMR defect have a high risk of developing colorectal cancer (CRC), endometrial cancer and various other cancers, most of which are diagnosed between the ages of 40 years and 60 years. ${ }^{1}$ In the last 15 years, an increasing number of patients have been described with biallelic MMR gene mutations in which MMR defects are inherited from both parents. This leads to a syndrome with recessive inheritance, which is referred to as 'constitutional mismatch repair-deficiency' (CMMR-D). The spectrum of cancers observed in patients with this syndrome differs from the spectrum found in LS, ${ }^{2}$ as about half develop brain tumours (BTs), around half develop digestive tract cancers and a third develop haematological malignancies. LS-associated tumours such as endometrial and urinary tract cancers also occur. A large proportion (up to $40 \%$ ) of patients with CMMR-D, even more than in LS, develop metachronous second malignancies. ${ }^{2}$ The prognosis of CMMR-D is much worse than that of LS due to the type of malignancies that occur and the high risk of second primary tumours.

BTs and haematological malignancies are mainly diagnosed in the first decade of life, and CRC and small bowel cancer (SBC) in the second and third decades of life. Endometrial cancers and urinary tract cancers are diagnosed in young adult patients with CMMR-D. A variety of non-malignant lesions may also be observed in CMMR-D, such as cafe au lait spots and other signs reminiscent of neurofibromatosis type-I, hypopigmentation, mild immunoglobulin deficiencies and congenital malformations.

Surveillance for CRC in patients with LS is very effective, as regular colonoscopy has been shown to reduce CRC-associated mortality by more than $60 \%{ }^{3}$ Therefore, an important question is whether surveillance for the most common CMMR-Dassociated cancers might also be effective. In view of the diverse nature of the malignancies associated with the syndrome, it is not clear whether early detection is possible and will improve the prognosis.

Recently, Durno et $a l^{4}$ published the outcome of a surveillance programme of two sisters with CMMR-D. Fifteen tumours were detected over a follow-up period of 10 years, including a jejunal carcinoma and a small asymptomatic anaplastic astrocytoma that could be completely resected. Sjursen $e t a l^{5}$ reported on a patient who was followed with upper and lower endoscopy, CT and MRI at regular intervals over a period of 26 years. 
During this time six adenocarcinomas (of the left colon, the duodenum, the distal ileum and the proximal ileum, the proximal jejunum and the endometrium, respectively), as well as several polyps of the large and small bowels and the stomach were removed.

More than four decades ago, a WHO proposal defined the criteria that should be met prior to implementation of large scale population screening. ${ }^{6}$ These criteria can also be applied in the assessment of surveillance of individuals with a genetic predisposition to cancer. The most important criteria include: (A) cancer should be a common problem in the group targeted for surveillance; (B) the natural course of the cancers should be known; (C) screening tests with high sensitivity and specificity should be available and the tests should be acceptable to the patient; (D) an effective treatment should be available following detection of a tumour; (E) there should be evidence that screening leads to diagnosis of cancer at an early stage and to an improvement in prognosis; and finally, (F) the surveillance protocol should be cost-effective.

Recently, a new European consortium was established with the aim of improving care for patients with CMMR-D. At a workshop of this collaborative group held in the Saint-Antoine Hospital, Paris, (9th of June, 2013), one of the issues addressed was the development of surveillance guidelines. A total of 20 experts in the field, including human and clinical geneticists, pathologists and paediatric oncologists from five countries, participated in the meeting. Experts in the field not present at the meeting were also involved in the discussions on surveillance. In this manuscript, the most important WHO surveillance criteria are addressed, and then applied to assess surveillance in CMMR-D. Based on the outcome of the workshop and the recommendations of European experts, the consortium now proposes a surveillance programme. In view of the lack of studies other than case reports, we did not use a system to grade the category of evidence of reported studies and/or strength of the recommendations.

\section{WHAT IS THE TUMOUR SPECTRUM IN CMMR-D?}

A total of 91 families with CMMR-D, including 146 patients, were identified in the world literature (Wimmer et al, in preparation). The most frequent underlying gene defects were PMS2 mutations, which were reported in approximately $60 \%$ of cases. The remaining $40 \%$ of cases were equally distributed among MSH6 and MLH1/MSH2 biallelic mutation carriers. The various cancers observed are summarised in table 1.

BTs and digestive tract cancers were the most common cancers, identified in $53 \%$ and $40 \%$ of patients, respectively. Among the BTs, the most common cancer was high grade glioma, followed by primitive neuroectodermal tumours (PNETs) and medulloblastoma. Glioblastomas and other high grade gliomas were much more frequent in CMMD-R than would be expected based on the relative contribution of these BTs to total paediatric malignancies in the general population. Digestive tract cancers included CRC (40\% of all CMMR-D cases) and SBC (12\% of all cases). Haematological cancers were observed in 31\% and included mainly $\mathrm{T}$ cell non-Hodgkin lymphoma (NHL) and acute leukaemia. Other LS-associated cancers (endometrial cancer, urinary tract cancer) were also observed in adults. In addition, a large variety of other tumours were found (table 2). The distribution of ages at diagnoses for BT, haematological malignancies, CRC and SBC reported in the literature are shown in figures $1-4$. It should be emphasised that the age distribution is biased by collection of published cases.
Table 1 Overview of the most common cancers observed in 146 patients with CMMR-D (Wimmer et al, in preparation)

\begin{tabular}{lc}
\hline Type of tumours & Number \\
\hline Haematological malignancies & 32 \\
NHL and other lymphoma & 9 \\
ALL & 5 \\
AML & 2 \\
Other & \\
Brain tumours & 58 \\
Glioblastoma and other high grade gliomas & 8 \\
(S)PNET & 7 \\
Medulloblastoma & 8 \\
Other & \\
Lynch syndrome-associated tumours & 59 \\
CRC & 18 \\
Small bowel cancers & 6 \\
Endometrial cancers & 5 \\
Other cancers & \\
\hline ALL, acute lymphoblastic leukaemia; AML, acute myeloid leukemia; CMMR-D, \\
constitutional mismatch repair-deficiency; CRC, colorectal cancer; NHL, non-Hodgkin \\
lymphoma; (S) PNET, (supratentorial) primitive neuroectodermal tumours.
\end{tabular}

\section{CLINICAL DESCRIPTION AND NATURAL COURSE OF THE MOST COMMON CANCERS OBSERVED IN CMMR-D \\ Brain tumours \\ Glioblastoma}

Glioblastomas are tumours that originate from glia cells. According to the WHO grading system (2007), these tumours are classified as grade IV. The common symptoms and signs are related to raised intracranial pressure and include headache, nausea and/or vomiting and diplopia. Other symptoms include epileptic insults, unusual behaviour, and signs and symptoms caused by compression of parts of the brain and nerves.

The mean age at diagnosis in patients with CMMR-D is 9 years (range 2-40 years) (Wimmer et al, in preparation). When a patient is diagnosed due to clinical symptoms, half of all patients already have advanced disease. The diagnosis is suspected with MRI or CT scanning and confirmed by histological examination of a biopsy. Glioblastoma are characterised by rapid progression, and the usual treatment consists of surgical resection (if possible), followed by radiotherapy and/or chemotherapy depending on the age of the child. Due to diffuse growth, complete resection of the tumour can be achieved in less than $50 \%$ of cases ${ }^{7}$ and the reported 2-year survival in patients with sporadic glioblastoma is $30-50 \% .^{78}$ The prognosis mainly depends on the completeness of the surgical resection. If the tumour is completely resected, a median survival of

Table 2 Other tumours observed in 146 patients with CMMR-D (Wimmer et al, in preparation)

Neuroblastoma

Wilms tumour

Ovarian neuroectodermal tumour

Infantile myofibromatosis

Rhabdomyosarcoma

Basal cell carcinoma

Mucoepidermoid carcinoma of the parotis

Osteosarcoma

CMMR-D, constitutional mismatch repair-deficiency. 


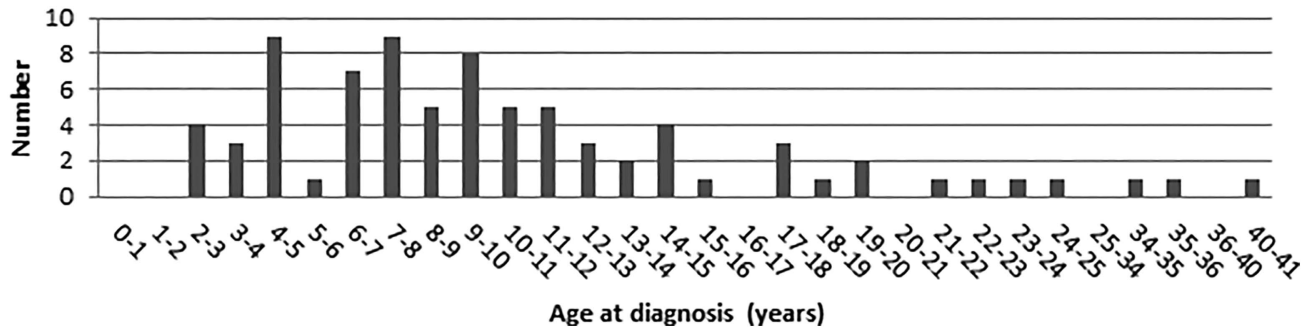

Figure 1 Age at diagnosis of brain tumours.

106 months has been reported. ${ }^{7}$ Glioblastoma is by far the most common cause of death in CMMR-D, it is not known whether the natural course and response to treatment of glioblastoma in CMMR-D differ from that of sporadic cases.

Other brain tumours

Other BTs reported in CMMR-D include medulloblastoma and (S)PNET. Medulloblastomas are located in the cerebellum and (S)PNET in other parts of the brain. These tumours derive from primitive neuroectodermal cells and are classified as WHO grade IV tumours. The mean age at diagnosis in patients with CMMR-D is 7 years (range $4-17$ years). Frequently occurring signs and symptoms are related to increased intracranial pressure (nausea, headache, early morning vomiting) and are usually already present for some time prior to diagnosis but go unrecognised. In the general population, the estimated median delay from the first symptoms to diagnosis is around 2 months. ${ }^{9}$ At presentation, about $30 \%$ of tumours have metastasised via cerebrospinal fluid to other parts of the central nervous system. The diagnosis can be established using MRI and CT scanning. To evaluate whether the tumour has metastasised to the spinal cord, spinal MRI and a lumbar puncture are necessary. Treatment usually consists of surgical resection, radiotherapy (except in cases $<3$ years old) and chemotherapy. The prognosis is strongly dependent on the presence of metastases, and the prognosis of patients without metastases is relatively good (survival 75\%) but neurocognitive consequences of brain radiotherapy may impair patient quality of life. Again, it is unknown whether the natural course of these tumours and the response to treatment in CMMR-D differ from that of sporadic cases.

\section{Digestive tract cancers: colorectal cancer and small bowel cancer \\ CRC}

It is generally accepted that most sporadic and hereditary colorectal cancers originate from adenomas. This also appears to hold for patients with CMMR-D, as colorectal adenomas are found in a third of all patients. ${ }^{2}$
Several studies have described digestive tract cancers in CMMR-D cases. In the 29 CMMR-D cases with CRC identified by Durno et al, ${ }^{10}$ the mean age at diagnosis was 16.4 years (range 8-28 years), 30 years younger than the typical age at diagnosis of CRC in LS. Information on the presence of adenomas was provided for a total of 18 out of the 29 patients with CRC. All but one had at least one adenoma, and 10 (55\%) had multiple adenomas with numbers usually between 10 and 100 . In addition, 11 out of 29 patients with CRC (38\%) had multiple CRCs. There was no predilection for a specific site in the colorectum.

Herkert et al described four patients with CMMR-D with intestinal cancer and polyposis and biallelic PMS2 mutations. In addition, these authors identified all PMS2 CMMR-D cases with gastrointestinal manifestations published in the literature between 1980 and December 2009. ${ }^{11}$ They found 25 cases with gastrointestinal (small bowel and colorectal) polyps (mean age at diagnosis 17 years; range $7-46$ years) and 42 cases with CRC (mean age at diagnosis 19; range 8-48 years). Full information on the colonic phenotype was available in 26 patients with CRC. Multiple adenomas ( $>10$ adenomas) were found in 18 out of the $26(70 \%)$ patients with CRC and multiple CRC in 38\% of the cases.

Patients with CRC develop symptoms and signs, such as rectal blood loss, at a relatively late stage, and around 50\% of the patients already have metastatic disease at diagnosis. The diagnosis of CRC is based on colonoscopy and confirmed by pathological examination of a tumour biopsy. The preferred treatment for CRC in young patients with LS is subtotal colectomy with ileorectal anastomosis (or proctocolectomy and ileal-pouch anal anastomosis in patients with rectal cancer). In patients with CMMR-D with multiple polyps (if there are too many to remove endoscopically and/or if they show high grade dysplasia) and patients with CRC, the treatment of choice would be colectomy with ileorectal anastomosis or proctocolectomy and construction of an ileal pouch-anal anastomosis.

Patients with stage III CRC (and advanced stage II CRC) receive chemotherapy, and those with rectal cancer are treated
Figure 2 Age at diagnosis of lymphoma/leukaemia.

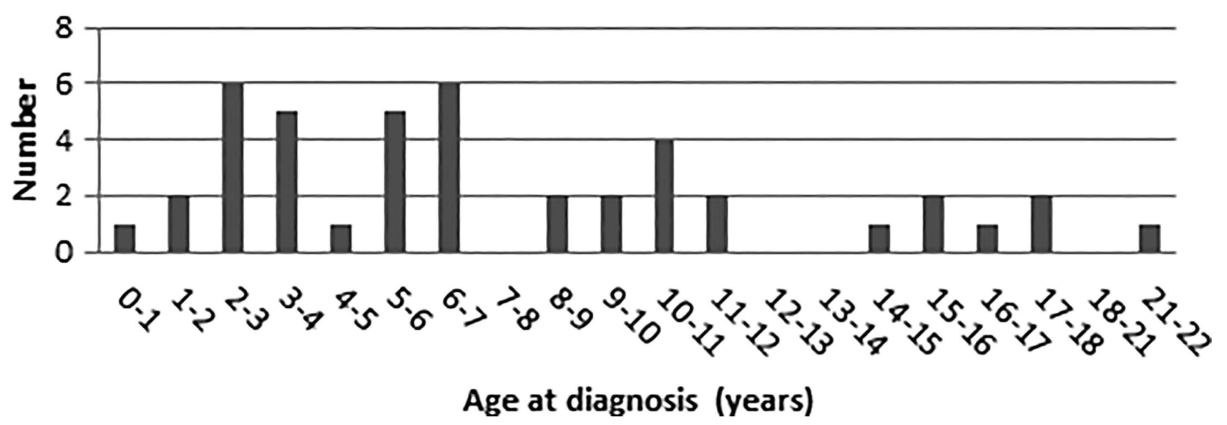




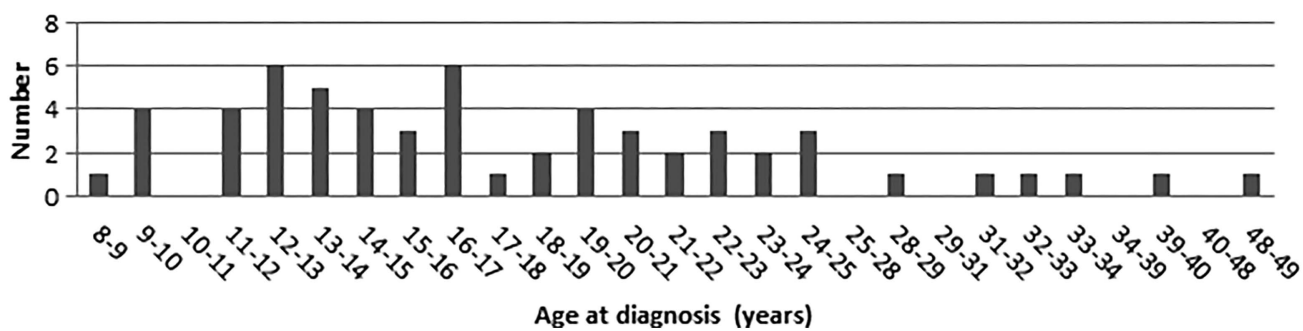

Figure 3 Age at diagnosis of colorectal cancer.

with radiotherapy. No specific side effects of radiotherapy have been reported in LS. However, the effectiveness and toxicity of chemotherapy and radiotherapy in CMMR-D is largely unknown (see below). Several studies have shown that there is an accelerated adenoma-carcinoma sequence in LS. Patients may develop CRC within 1-2 years after a normal colonoscopy. Our experience, supported by data from the literature on CMMR-D, indicates that adenoma and CRC development are also characterised by rapid progression. The 5 -year survival for CRC in LS is approximately $50-60 \%$.

\section{Small bowel cancer}

Cancer of the small bowel is also thought to originate from adenomas. Duodenal adenomas are found in 5\% of CMMR-D cases (Wimmer et al, in preparation). In a series of 42 primary SBCs in LS, the mean age at diagnosis was 49 years (range 25-88 years), about $10-15$ years younger than in sporadic SBC. ${ }^{12}$ Based on 18 SBCs in 12 patients, the mean age at diagnosis in CMMR-D is 25 years (11-42 years) (Wimmer et al, in preparation).

Herkert et $a l^{11}$ identified 25 cases with gastrointestinal (small bowel and colorectal) polyps (mean age at diagnosis 17 years; range $7-46$ years) in the medical literature, and 11 with SBC (mean age at diagnosis 27; range 11-42 years).

About $50 \%$ of sporadic SBCs are located in the duodenum and $10-15 \%$ in the ileum, whereas in LS the cancers are more evenly distributed along the small bowel. ${ }^{12}$ The 11 PMS2 CMMR-D literature cases identified by Herkert et al ${ }^{11}$ developed 18 SBCs, including 8 duodenal cancers, 7 jejunal cancers and 3 ileal cancers. Three of the 11 patients developed multiple (up to 5) SBCs. 5

In general, SBCs go unnoticed for a long period or manifest with only non-specific symptoms such as dull, cramping abdominal pain, abdominal distention and (faecal occult) blood loss. Obstruction is also a common presentation.

The diagnostic modalities used for assessing the presence of SBC are radiographic imaging (CT or MRI enteroclysis) and endoscopy (upper gastrointestinal (GI) endoscopy and ileocolonoscopy, for the detection of cancers located in the duodenum and ileum, respectively). There is also an increasing use of video capsule endoscopy (VCE) and double balloon enteroscopy. The effects of chemotherapy and radiotherapy are disappointing, ${ }^{13}$ and the treatment of choice is surgical resection. The 5 -year survival rate of patients with resected tumours is around $50 \%$. The natural history and prognosis of patients with CMMR-D with SBC are unknown.

\section{Haematological cancers \\ Non-Hodgkin lymphoma}

NHL is the most commonly occurring haematological cancer in CMMR-D (Wimmer et al, in preparation), with $\mathrm{T}$ cell NHL more frequently observed than B cell NHL. T cell NHL is usually located in the mediastinum, while B cell NHL has a mainly intra-abdominal location but is sometimes seen in the cervical region. Signs and symptoms vary depending on the type of lymphoma and the location, but may include coughing and respiratory distress ( $\mathrm{T}$ cell NHL), obstruction of the bowel (B cell NHL), cervical lymphadenopathy, difficulty with swallowing (also seen in B cell NHL), and anaemia, tiredness and bruises in cases with bone marrow involvement.

Ages at diagnosis of sporadic NHL vary from 5 years to 12 years, according to histological subtypes. ${ }^{14}$ The median age at diagnosis of NHL in CMMR-D is 5 years (range 0.417 years), based on 31 cases (Wimmer et al, in preparation). In the general population, the median time to diagnosis, defined as the interval between the first signs and symptoms and diagnosis, is relatively brief $\left(3.8\right.$ weeks). ${ }^{9}$ The techniques used to diagnose and stage NHL may include ultrasound of the abdomen, lymph nodes and testes, MRI or CT scanning, fluorodeoxyglucose-positron emission tomography (FDG-PET) scanning, biopsy of the tumour, bone marrow biopsy and lumbar puncture. Treatment for NHL consists mainly of intensive chemotherapy, with radiotherapy restricted to the small percentage of patients with overt
Figure 4 Age at diagnosis of small bowel cancer.

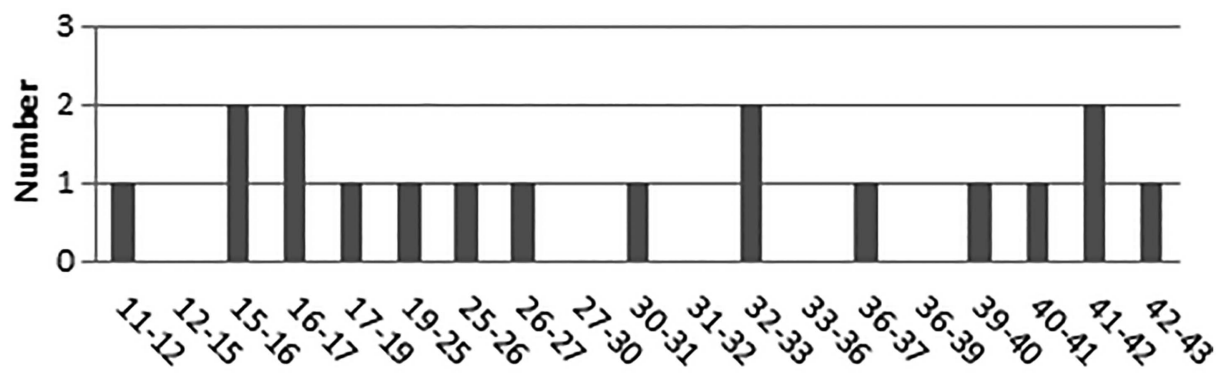

Age at diagnosis (years) 
central nervous system (CNS) disease at the time of diagnosis. The duration of treatment varies from a few weeks to 2 years, depending on the stage and the histological subtype. The prognosis is relatively good, with survival rates of $70-90 \%$. The natural course and response to treatment of NHL associated with CMMR-D is unknown.

\section{Acute leukaemia}

The most common form of acute leukaemia in CMMR-D is acute lymphoblastic leukaemia (ALL). The mean age at diagnosis of ALL in CMMR-D is 6 years (range 2-21 years), based on nine cases (Wimmer et al, in preparation). The incidence of ALL peaks between 2 years and 5 years in non-CMMR-D. Children with ALL often present with signs and symptoms that reflect bone marrow infiltration and/or extramedullary disease including anaemia, thrombocytopenia, neutropenia and lymphadenopathy. Other presenting signs and symptoms are bone pain, fever, fatigue, bleeding and respiratory distress. The median time from the presentation of signs and symptoms to diagnosis is only 1-2 weeks. ${ }^{9}$ Tests required to classify ALL include immunotyping, cytogenetic studies and molecular studies to identify translocations. Lumbar puncture is performed to assess the involvement of the CNS. The diagnosis of ALL is confirmed by a bone marrow aspiration and biopsy. Although the treatment of ALL is primarily based on chemotherapy, the different forms of ALL require different approaches for optimal results. The prognosis of ALL depends on the clinical and laboratory features and the response to treatment. Overall, the cure rate of patients without CMMR-D with ALL is greater than $80 \%$.

\section{CONSIDERATIONS REGARDING THE SURVEILLANCE PROGRAMME IN PATIENTS WITH CMMR-D \\ Brain tumours}

MRI scanning is the best screening method for the early detection of BT. Repeated CT scanning of the brain should be avoided because of the possible induction of tumours due to radiation.

As previously mentioned, glioblastomas usually show diffuse growth, meaning that discrimination between normal and tumour tissue may be impossible and the precise extent of the tumour may be difficult to assess. MRI scanning in young children is usually performed under general anaesthesia. MRI starting from birth is recommended by Durno et al. ${ }^{4}$ The youngest patients with CMMR-D diagnosed with glioblastoma were 2 years old. Therefore, we recommend commencing MRI scanning at the age of 2 years, and due to rapid progression, scanning at an interval of $6-12$ months is probably needed. Whether early detection will lead to more complete surgical resections and improved survival is presently unknown.

\section{Digestive tract cancer: CRC}

Many studies have demonstrated that colonoscopy has the highest sensitivity and specificity and is thus the best tool for surveillance of the colon. In LS, small, flat and non-polypoid lesions are frequent and can easily be missed. ${ }^{15}{ }^{16}$ We also observed mainly multiple non-polypoid lesions in a patient with CMMR-D. Therefore, it is recommended that chromoscopy be used in order to allow the detection and delineation of small, flat lesions. In children, colonoscopy is performed under general anaesthesia.

Based on experience with LS, surveillance of the colon is expected to be effective. Due to the assumed high progression rate from an adenoma to colorectal cancer, an intensive surveillance programme at annual intervals is probably needed. In patients with multiple adenomas, a shorter interval of 6 months is recommended. Because most cancers develop in the second decade of life, the programme can be started by the age of 8 years. In view of the large non-polypoid lesions often observed in CMMR-D, a paediatric gastroenterologist should perform the procedure together with an 'adult' gastroenterologist with experience of endoscopic mucosal resection of such tumours.

\section{Digestive tract cancer: small bowel cancer}

For the detection of duodenal cancers, an upper GI endoscopy can be performed (at the same time as colonoscopy). During colonoscopy, the terminal ileum should also be intubated for the identification of ileal cancer. CT scanning and MRI enteroclysis can be used for the detection of SBC located in the jejunum and remaining ileum but these modalities are too burdensome for surveillance purposes. A major disadvantage of regular CT scanning is the radiation burden. VCE is probably the best tool. Two studies in LS have shown that adenomas and SBC can be detected using VCE. In a French study by Saurin, tumours were detected in $10 \%$ of cases (one jejunal cancer, two adenomas). ${ }^{17}$ However, in a Dutch study on 200 LS mutation carriers, a tumour (one adenoma and one cancer) was identified in only $1.5 \%$ of cases (Haanstra et al submitted 2013). In this study, one patient developed a SBC 6 months after a normal VCE. The value of surveillance of the small bowel using VCE is therefore unknown. However, the high prevalence of such tumours $(8 \%)$ in CMMD-R may justify the use of VCE. Because SBC below age 10 years is very rare, the surveillance programme can be started at the age of 10 years. Young children are generally able to swallow the capsule. An alternative is to place the capsule endoscopically during upper GI endoscopy. ${ }^{11}$

\section{Non-Hodgkin lymphoma}

Because sporadic $\mathrm{T}$ cell and B cell lymphomas have an excellent outcome, the benefit of early diagnosis is not obvious except for the avoidance of life threatening situations at diagnosis for patients with huge mediastinal masses. We currently have no information on the natural history of these lymphomas in CMMR-D, and while the natural course of the disease might differ from sporadic cases, sporadic cases usually present with rapidly growing tumours and clinical manifestations within a month prior to diagnosis. Thus, screening at less than 3 -month intervals would probably be inefficient, whereas this frequency is probably too high for a screening for which we are not sure that it would improve the cure rate. A reasonable alternative is to perform clinical examinations, and optionally, abdominal ultrasound every 6 months. This strategy would probably be inefficient for early diagnosis but it might provide useful information on the natural history of this lymphoma in patients with CMMR-D.

\section{Acute lymphocytic leukaemia/acute myeloid leukaemia}

Signs and symptoms of acute leukaemia are apparent within a short period of time. As most patients with ALL have anaemia, thrombocytopenia with a normal or depressed white blood cells and lymphoblasts on peripheral smear, regular assessment of the blood count may be recommended but it is uncertain whether surveillance will lead to early detection and improvement of the prognosis.

\section{CHEMOTHERAPY IN LYNCH SYNDROME AND CMMR-D}

About $15 \%$ of CRCs shows microsatellite instability (MSI), which is a marker of MMR deficiency. In sporadic CRC, MSI 
results from somatic MMR inactivation mainly due to epigenetic changes in the tumour, whereas in LS, MSI is caused by biallelic MMR gene inactivation due to a heterozygous germ line mutation and a somatic second-hit alteration in the other allele. Patients with CMMR-D show MSI due to a constitutional MMR defect caused by biallelic germ line MMR gene mutations.

A number of studies have evaluated the effectiveness of chemotherapy in the subgroup of CRC with MMR deficient versus MMR proficient tumours. Chemotherapy is the mainstay of treatment of many cancers in childhood. Due to the rarity of CMMR-D, very limited information on the optimal chemotherapy is available. Several studies have demonstrated that tumours with loss of MMR function are more frequently resistant to certain forms of chemotherapy. ${ }^{18}$ Another major concern is that some of these chemotherapeutic agents are mutagenic and may increase the risk of developing therapy-induced cancers, because patients with CMMR-D have a defect in DNA damage signalling and are unable to repair the accumulated somatic mutations. ${ }^{19}$

The effectiveness of chemotherapy in MMR-deficient CRC has recently been reviewed by Devaud and Gallinger. ${ }^{20}$ Evaluation of clinical trials performed in the 20th century that compared fluorouracil (5FU) with no treatment ${ }^{21} 22$ demonstrated that MSI-high (MSI-H) tumours (retrospectively analysed) were resistant to treatment with 5FU. These observations were confirmed by many in vitro studies. ${ }^{23}$ The resistance to $5 \mathrm{FU}$ of MMR-deficient cancer cells may be due to the incorporation of fluorouracil metabolites into DNA, although the sensitivity of
MMR-deficient cell lines to this drug and other agents is likely to be dependent on the status of HSP110, a molecular chaperone that has been reported to be mutated in MMR-deficient tumours, sensitising MSI-tumour cells to a wide spectrum of anticancer agents including 5-FU ${ }^{24}$ (Collura A, Gastroenterology, in press).

Although studies of MMR-deficient cell lines reported resistance to cisplatin and carboplatin, a good response to oxaliplatin was found and this was subsequently confirmed in clinical trials. ${ }^{1325-28}$ Irinotecan also appears to be effective, similarly as in MMR-proficient tumours. ${ }^{29-32}$ Moreover, a recent study using cell lines showed a good response to irinotecan in combination with thymidine. ${ }^{33}$

Most of the above mentioned studies were performed in patients with somatic deficient MMR tumours. Less is known about the response in patients with LS and patients with CMMR-D with CRC.

All patients with CMMR-D with CRC and treated with chemotherapy described in the literature are shown in table $3 .^{34-43}$ Most patients appear to show a response similar to the response in patients with sporadic CRC. However, prospective studies are needed to confirm this observation.

In 2007 , Scott et $a l^{44}$ discussed the effectiveness of chemotherapy in patients with CMMR-D. Several cell line and mouse model studies showed that tumours are resistant to treatment with O6-methylating agents. ${ }^{18}$ One of these agents (temozolomide) is frequently used in the standard treatment of glioblastoma. This drug causes mutations in tumour DNA that cannot be repaired by patients with a loss of MMR function. Indeed,

Table 3 Response of colorectal cancer (CRC) to chemotherapy in CMMR-D

\begin{tabular}{|c|c|c|c|c|c|c|c|c|}
\hline Author/year & $\begin{array}{l}\text { Type of } \\
\text { tumour }\end{array}$ & $\begin{array}{l}\text { Gene } \\
\text { defect }\end{array}$ & $\begin{array}{l}\text { Age } \\
\text { (years) }\end{array}$ & Surgery & Chemotherapy & $\begin{array}{l}\text { Radio } \\
\text { therapy }\end{array}$ & Response & Status \\
\hline Gallinger/2004 & $3 \times C R C$ & MLH1 & 9 & Subtotal colectomy (3 polyps) & $\begin{array}{l}\text { Irinotecan, 5FU, } \\
\text { leucovorin }\end{array}$ & No & $\begin{array}{l}\text { No evidence } \\
\text { recurrence }\end{array}$ & After 11 months alive \\
\hline Gururangan/2007 & CRC sigmoid & PMS2 & 14 & Pancolectomy & 5FU, leucovorin & Yes & $\begin{array}{l}\text { No evidence } \\
\text { recurrence }\end{array}$ & $\begin{array}{l}\text { Died } 7 \text { years later from brain } \\
\text { tumour }\end{array}$ \\
\hline \multirow[t]{2}{*}{ Tan/2008 } & CRC & PMS2 & 15 & Low anterior resection & FOLFOX4/12x & No & & \\
\hline & & & & $\begin{array}{l}\text { Panproctocolectomy }(3 \times C R C, \\
>10 \text { polyps in specimen) }\end{array}$ & & & Not reported & Not reported \\
\hline \multirow[t]{2}{*}{ Jackson/2008 } & $\begin{array}{l}\text { CRC sigmoid } \\
\text { liver } \\
\text { metastases }\end{array}$ & PMS2 & 14 & $\begin{array}{l}\text { Resection sigmoid, partial liver } \\
\text { resection; colectomy }\end{array}$ & Oxaliplatin, capacitabine. & & & $\begin{array}{l}5 \text { months later recurrence rectal } \\
\text { cancer }\end{array}$ \\
\hline & & & 14 & $\begin{array}{l}\text { Resection rectal cancer, RFA liver } \\
\text { metastases, }\end{array}$ & $\begin{array}{l}\text { Irinotecan, 5FU, } \\
\text { bevacizumab }\end{array}$ & & Not reported & Alive \\
\hline Kruger/2008 & Sigmoid CRC & PMS2 & 13 & $\begin{array}{l}\text { Sigmoid resection, later } \\
\text { panproctocolectomy (multiple } \\
\text { polyps, CRC right colon) }\end{array}$ & FOLFOX/10 months & No & $\begin{array}{l}\text { No evidence } \\
\text { recurrence }\end{array}$ & Alive \\
\hline Rahner/2008 & $4 \times C R C$ & MSH6 & 17 & Colectomy & Cetuximab & No & & Not reported \\
\hline Kratz/2009 & CRC & PMS2 & 8 & Transversectomy & FOLFOX & & & Alive \\
\hline \multirow[t]{2}{*}{ Toledano/2009 } & $\begin{array}{l}\text { Rectal cancer, } \\
20 \text { polyps }\end{array}$ & MSH2 & 14 & Panproctocolectomy (100 polyps) & FOLFOX & Yes & & Relapse after 2 months \\
\hline & & & & & FOLFIRI/avastin & & & $\begin{array}{l}\text { Died } 12 \text { months after diagnosis } \\
\text { from brain tumour }\end{array}$ \\
\hline \multirow[t]{2}{*}{ Vasovcak/2012 } & Rectal cancer & PMS2 & 13 & Resection & $\begin{array}{l}\text { Capecitabine, oxaliplatin, } \\
\text { followed by cetuximab, } \\
\text { irinotecan }\end{array}$ & & & Resistant after 4 cycles \\
\hline & & & & & & Yes & & $\begin{array}{l}\text { Died after short remission } \\
17 \text { months later }\end{array}$ \\
\hline Lindsay/2013 & $\begin{array}{l}\text { CRC, liver } \\
\text { metastases }\end{array}$ & PMS2 & 12 & Left hemicolectomy & $\begin{array}{l}\text { Folinic acid, 5FU, } \\
\text { oxaliplatin; later } \\
\text { irinotecan, 5FU, } \\
\text { Leucovorin }\end{array}$ & No & $\begin{array}{l}\text { Partial } \\
\text { remission }\end{array}$ & $\begin{array}{l}2 \text { years later new liver } \\
\text { metastases; died from progressive } \\
\text { leukoencephalopathy }\end{array}$ \\
\hline
\end{tabular}


investigation of a clinical specimen from a patient treated with this drug showed an accumulation of somatic mutations (mutator phenotype). ${ }^{45}$ In vitro studies showed a similar effect for busulfan but not for chloroethylating agents such as cyclophosphamide and melphalan. ${ }^{18}$

MSI occurs in some tumours following therapy with thiopurines or cisplatin, suggesting that MMR deficiency is important in clinical resistance. ${ }^{46-48}$ In addition, MMR deficiency appears to be common in resistant acute myeloid leukemia and is a recurrent feature of secondary NHL occurring in allografted patients treated with azathioprine. ${ }^{49-51}$ A report on two patients with glioblastoma showed that they were resistant to treatment with temozolomide. ${ }^{52}$ Another study demonstrated loss of MSH6 expression in a subset of patients with glioblastoma resistant to temozolomide. ${ }^{53}$

All patients with CMMR-D known from literature with

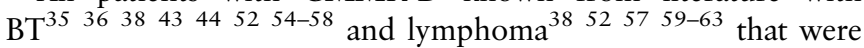
treated with chemotherapy are listed in tables 4 and 5. Most patients with $\mathrm{T}$ cell lymphomas showed a good response to chemotherapy. However, chemotherapy in patients with BT had a less favourable outcome. In particular, only one out of six

Table 4 Response of brain tumours (BTs) to chemotherapy in CMMR-D

\begin{tabular}{|c|c|c|c|c|c|c|c|c|}
\hline Author /year & $\begin{array}{l}\text { Brain tumour } \\
\text { (gene defect) }\end{array}$ & $\begin{array}{l}\text { Age } \\
\text { (years) }\end{array}$ & Surgery & Chemotherapy & Radiotherapy & Response & Outcome & Status \\
\hline Menko/2004 & $\begin{array}{l}\text { Oligodendroma } \\
\text { (MSH6) }\end{array}$ & 10 & $\begin{array}{l}\text { Partial } \\
\text { resection }\end{array}$ & Not specified & Yes & Partial remission & Recurrence of BT & $\begin{array}{l}\text { Died at } 12 \text { years from } \\
\text { BT }\end{array}$ \\
\hline \multirow[t]{2}{*}{ Gurugangan/2007 } & $\begin{array}{l}\text { Astrocytoma grade III } \\
\text { (PMS2) }\end{array}$ & 19 & $\begin{array}{l}\text { Subtotal } \\
\text { resection }\end{array}$ & Temozolonide after RT & Yes & Resistant & New BT & \\
\hline & & 19 & & $\begin{array}{l}\text { Carmustine and } \\
\text { irinotecan }\end{array}$ & & $\begin{array}{l}\text { "Very good" } \\
\text { partial } \\
\text { remission }\end{array}$ & $\begin{array}{l}18 \text { months later } \\
\text { minimal uptake scan }\end{array}$ & $\begin{array}{l}\text { Died } 22 \text { months later } \\
\text { from progression BT }\end{array}$ \\
\hline Scott/2007 & $\begin{array}{l}\text { Medulloblastoma } \\
\text { (MSH6) }\end{array}$ & 7 & $\begin{array}{l}\text { Not } \\
\text { specified }\end{array}$ & $\begin{array}{l}\text { SIOP PNET 3: vincristine, } \\
\text { cyclophosphamide } \\
\text { etoposide, carboplatin }\end{array}$ & $\begin{array}{l}\text { Yes spinal } \\
\text { cord }\end{array}$ & $\begin{array}{l}\text { Complete } \\
\text { response }\end{array}$ & & Alive at 13 years \\
\hline $\operatorname{Tan} / 2008$ & Glioblastoma (PMS2) & 8 & No & $\begin{array}{l}\text { Temozolomide later: } \\
\text { temozolomide and } \\
\text { lomustin }\end{array}$ & Yes & Resistant & $\begin{array}{l}\text { Leptomeningeal } \\
\text { disease }\end{array}$ & $\begin{array}{l}\text { Died } 10 \text { months after } \\
\text { diagnosis }\end{array}$ \\
\hline Etzler/2008 & $\begin{array}{l}\text { Medulloblastoma } \\
\text { (MSH6) }\end{array}$ & 6 & $\begin{array}{l}\text { Gross total } \\
\text { resection }\end{array}$ & Cisplatin CCNU vincristine & $\begin{array}{l}\text { Yes spinal } \\
\text { cord }\end{array}$ & Not reported & MDS/AML at 9 & Died 36 months later \\
\hline Kruger/2008 & Glioblastoma (PMS2) & 6 & $\begin{array}{l}\text { Surgical } \\
\text { resection }\end{array}$ & Yes not specified & Yes & $\begin{array}{l}\text { Complete } \\
\text { remission }\end{array}$ & $\begin{array}{l}\text { Recurrent BT } 10 \text { years } \\
\text { later }\end{array}$ & $\begin{array}{l}\text { Died at age } 16 \text { years } \\
\text { from relapse of } B T\end{array}$ \\
\hline Kruger/2008 & Glioblastoma (PMS2) & 6 & $\begin{array}{l}\text { Surgical } \\
\text { resection }\end{array}$ & Yes not specified & Yes & Resistant & Unresectable tumour & Died at age 7 years \\
\hline \multirow[t]{2}{*}{ Ilencikova/2011 } & $\begin{array}{l}\text { Fibrillar astrocytoma } \\
\text { (MSH6) }\end{array}$ & 11 & No & POG 9233/34 & Yes & Resistant & $\begin{array}{l}<1 \text { year new tumour, } \\
\text { anaplastic } \\
\text { astrocytoma III }\end{array}$ & \\
\hline & & 11 & & $\begin{array}{l}\text { HIT-AGG-2007 plus } \\
\text { temozolomide }\end{array}$ & Yes & Resistant & & Died 3 months later \\
\hline Ilencikova/2011 & Glioblastoma (MSH6) & 10 & $\begin{array}{l}\text { Surgical } \\
\text { resection }\end{array}$ & Temozolomide & Yes & Resistant & Progression & Died at age 11 years \\
\hline \multirow[t]{4}{*}{ Johannes-ma/2011 } & Cystic glioma (PMS2) & 11 & Resection & No & No & & $\begin{array}{l}\text { Recurrence after } \\
7 \text { months }\end{array}$ & \\
\hline & & 11 & Debulking & $\begin{array}{l}\text { Vincristine, carboplatin, } \\
\text { VP16, etoposide }\end{array}$ & Yes & Partial response & $\begin{array}{l}\text { New tumour after } \\
2 \text { years, } 8 \text { months, } \\
\text { high grade glioma }\end{array}$ & \\
\hline & & 14 & & $\begin{array}{l}\text { Carboplatin, melfalan, } \\
\text { bone marrow } \\
\text { transplantation }\end{array}$ & Yes & Partial response & $\begin{array}{l}\text { Recurrence } 3 \text { years, } \\
4 \text { months later }\end{array}$ & \\
\hline & & 18 & & temozolomide & Yes & Resistant & & Died at age 19 years \\
\hline Baas/2013 & Glioblastoma (PMS2) & 3 & $\begin{array}{l}\text { Surgical } \\
\text { resection }\end{array}$ & Temozolomide & Yes & $\begin{array}{l}\text { Partial response; } \\
\text { " } 26 \text { months } \\
\text { healthy" }\end{array}$ & & $\begin{array}{l}\text { Died at } 5 \text { years } \\
6 \text { months due to sepsis } \\
\text { during chemotherapy } \\
\text { for NHL }\end{array}$ \\
\hline Baas/2013 & $\begin{array}{l}\text { Anaplastic } \\
\text { astrocytoma/spin al } \\
\text { cord (MLH1) }\end{array}$ & $\begin{array}{l}2 \text { years } \\
10 \text { months }\end{array}$ & $\begin{array}{l}\text { Surgical } \\
\text { resection }\end{array}$ & HIT-GBM-D protocol & Yes & Partial response & & $\begin{array}{l}\text { Died at } 6 \text { years and } \\
3 \text { months due to sepsis } \\
\text { during chemotherapy } \\
\text { for NHL }\end{array}$ \\
\hline Lindsay/2013 & $\begin{array}{l}\text { Medulloblastoma and } \\
\text { metastatic CRC } \\
\text { (PMS2) }\end{array}$ & 12 & $\begin{array}{l}\text { Complete } \\
\text { resection }\end{array}$ & $\begin{array}{l}\text { Folinic acid, 5FU, } \\
\text { oxaliplatin for CRC }\end{array}$ & $\begin{array}{l}\text { Yes } \\
\text { craniospinal }\end{array}$ & $\begin{array}{l}\text { Complete } \\
\text { response }\end{array}$ & & $\begin{array}{l}\text { Died } 2 \text { years later from } \\
\text { liver metastasis }\end{array}$ \\
\hline \multirow[t]{2}{*}{ Yeung/2013 } & $\begin{array}{l}\text { Optic pathway glioma } \\
\text { (PMS2) }\end{array}$ & 3 & No & Carboplatin, vincristine, & & Partial response & GH-excess & $\begin{array}{l}\text { Stable disease during } \\
41 / 2 \text { years }\end{array}$ \\
\hline & & 8 & & $\begin{array}{l}\text { Vinblastine followed by } \\
\text { temozolomide }\end{array}$ & & Resistant & & $\begin{array}{l}\text { Increased activity scan, } \\
\text { alive }\end{array}$ \\
\hline
\end{tabular}


Table 5 Response of NHL to chemotherapy in CMMR-D

\begin{tabular}{|c|c|c|c|c|c|c|c|}
\hline Author/year & $\begin{array}{l}\text { Type of } \\
\text { lymphoma }\end{array}$ & $\begin{array}{l}\text { Gene } \\
\text { defect }\end{array}$ & $\begin{array}{l}\text { Age } \\
\text { (years) }\end{array}$ & Chemotherapy & Other therapy & Response & Outcome/status \\
\hline $\begin{array}{l}\text { Ostergaard/ } \\
2005\end{array}$ & T cell NHL & MSH6 & 10 & Yes & No & Partial remission & $\begin{array}{l}\text { Died from progression } 6 \text { months } \\
\text { later }\end{array}$ \\
\hline \multirow[t]{2}{*}{ Scott/2007 } & \multirow[t]{2}{*}{ T cell NHL } & \multirow[t]{2}{*}{ MSH2 } & 2.5 & BFM-NHL95 \& MRC ALL 97/99 & No & Partial remission & $\begin{array}{l}\text { Recurrence } 2 \text { weeks after } \\
\text { completion of chemotherapy }\end{array}$ \\
\hline & & & 2.5 & $\begin{array}{l}\text { MRC ALL R3 protocol (minus } \\
\text { cyclophosphamide) etoposide }\end{array}$ & $\begin{array}{l}\text { Total body RT, peripheral blood } \\
\text { stem cell transplantation }\end{array}$ & $\begin{array}{l}\text { Complete } \\
\text { remission }\end{array}$ & Alive, 6 years \\
\hline Kratz/2008 & T cell NHL & PMS2 & 6 & BFM-NHL95 & No & $\begin{array}{l}\text { Complete } \\
\text { remission }\end{array}$ & Alive, 16 years \\
\hline Kruger/2008 & T cell NHL & PMS2 & 10 & Euro-LB 02 & No & $\begin{array}{l}\text { Complete } \\
\text { remission }\end{array}$ & Alive \\
\hline \multirow[t]{2}{*}{ Peters/2009 } & \multirow[t]{2}{*}{ T cell NHL } & \multirow[t]{2}{*}{ MSH6 } & 8 & $\begin{array}{l}\text { Children's oncology group protocol } \\
\text { A } 5971\end{array}$ & No & $\begin{array}{l}\text { Complete } \\
\text { remission }\end{array}$ & Relapse 9 months after diagnosis \\
\hline & & & $8-9$ & $\begin{array}{l}\text { ifosfamide, cisplatin, etoposide, } \\
\text { nelarabine }\end{array}$ & Radiotherapy & Resistant & Progression, died at age 9 years \\
\hline \multirow[t]{2}{*}{$\begin{array}{l}\text { Ripperger/ } \\
2010\end{array}$} & \multirow[t]{2}{*}{ T cell NHL } & \multirow[t]{2}{*}{ MSH6 } & \multirow[t]{2}{*}{6} & BFM-NHL95 & No & Not specified & $\begin{array}{l}\text { Relapse } 6 \text { months after } \\
\text { completion of chemotherapy }\end{array}$ \\
\hline & & & & ALL REZ BFM 2002 & $\begin{array}{l}\text { Haematopoietic stem cell } \\
\text { transplantation }\end{array}$ & $\begin{array}{l}\text { Complete } \\
\text { remission }\end{array}$ & Alive 7 years later \\
\hline $\begin{array}{l}\text { Ilencikova/ } \\
2011\end{array}$ & T cell NHL & MSH6 & 11 & Euro-LB 2002 & & Good response & Died from BT $<1$ year \\
\hline Baas/2013 & T cell NHL & MLH1 & 5.5 & Children's oncology group-A5971 & No & & Died from staphylococcal sepsis \\
\hline \multirow[t]{2}{*}{ Baas/2013 } & \multirow[t]{2}{*}{ B cell NHL } & \multirow[t]{2}{*}{ PMS2 } & \multirow[t]{2}{*}{9} & SNWLK-94 & No & $\begin{array}{l}\text { Complete } \\
\text { remission }\end{array}$ & 11years, 6 months: T cell NHL \\
\hline & & & & Euro LB-02 protocol & No & Not reported & \\
\hline Baas/2013 & T cell NHL & PMS2 & 5.5 & Euro LB-02 & No & $\begin{array}{l}\text { "Initially good } \\
\text { response" }\end{array}$ & $\begin{array}{l}\text { Died } 9 \text { months later from sepsis } \\
\text { during bone marrow aplasia }\end{array}$ \\
\hline
\end{tabular}

ALL, acute lymphoblastic leukaemia; CMMR-D, constitutional mismatch repair-deficiency; NHL, non-Hodgkin lymphoma.

patients treated with temozolomide and radiotherapy showed a partial response. In the other patients, the tumour was resistant to treatment.

Whether temozolomide or other drugs such as cisplatin and busulfan are contraindicated in CMMR-D is currently controversial and requires further studies. As stated by Scott et al, ${ }^{44}$ early detection of tumours may allow considerations about the most effective chemotherapeutic regimen.

\section{DISCUSSION}

For many types of cancers, diagnosis at the earliest possible (preferably preclinical) stage results in much more effective treatment and an improved prognosis. This may also be the case for CMMR-D. Based on the available knowledge and the discussions at the workshop, the European consortium proposed a surveillance protocol as summarised in table 6 . The surveillance for CRC is the only aspect that largely complies with the WHO criteria for screening, although it is unknown whether colonoscopic surveillance in CMMR-D is as effective as in LS. The value of all other suggested screening protocols is unknown. In particular, it is questionable whether surveillance for ALL and NHL improves the already favourable outcome for patients with these tumours. A randomised controlled trial is needed to assess whether surveillance can improve the prognosis. However, the question then arises whether it is ethically justified not to offer surveillance in view of the high mortality without surveillance.

Table 6 Surveillance protocol for patients with CMMR-D proposed by the European consortium

\begin{tabular}{|c|c|c|}
\hline Type of cancer & Lower age limit & Procedure/interval \\
\hline Brain tumours & From age 2 years & MRI, $1 \times / 6-12$ months \\
\hline \multicolumn{3}{|l|}{ Digestive tract cancer } \\
\hline SBC & From age 10 years & VCE, upper gastrointestinal endoscopy*; $1 \times /$ year \\
\hline CRC & From age 8 years & Ileocolonoscopy; 1×/year; \\
\hline \multicolumn{3}{|c|}{ Haematological malignancies } \\
\hline NHL/other lymphoma & From age 1 year & $\begin{array}{l}\text { Clinical examination } 1 \times / 6 \text { months } \\
\text { Optional: abdominal ultrasound } 1 \times / 6 \text { months }\end{array}$ \\
\hline Leukaemia & From age 1 year & Blood count $1 \times / 6$ smonths \\
\hline LS-associated cancerst & From age 20 years & $\begin{array}{l}\text { Gynaecological examination, transvaginal US, Pipelle curettage }(1 \times / \text { year }) \text {, } \\
\text { Urine cytology, dipstick ( } 1 \times / \text { year })\end{array}$ \\
\hline All cancers & \multicolumn{2}{|c|}{$\begin{array}{l}\text { Parents and patients should be advised to contact their doctor in case of unusual signs or symptoms. A pamphlet } \\
\text { should be available with information about the signs/symptoms that may occur. }\end{array}$} \\
\hline
\end{tabular}


Table 7 Pros and cons of participating in a surveillance programme

Pros

1. Possible early detection of BTs, allowing complete resection

2. Early detection of adenomas in the small bowel and colorectum before malignant degeneration

3. Early detection of BTs, which allows the most effective surgery and chemotherapeutic regimen to be determined4. Early detection of NHL and leukaemia, which allows the most effective chemotherapeutic regimen to be determined

\section{Cons}

1. Brain MRI may reveal small lesions of unknown significance. The only management is follow-up MRI at a short interval, which may increase anxiety

2. Claustrophobia (MRI) in adults

3. Video capsule endoscopy: risk of retaining capsule

4. Colonoscopy: risk of perforation (1/1000) and risk of bleeding after polypectomy (3-4\%)

5. Greater awareness of being at high risk for developing cancers

6. Increased psychological distress before and after surveillance examination

7. Uncertainty about effectiveness of prevention programme and early treatment8. Complications of general anaesthesia

BT, brain tumour; NHL, non-Hodgkin lymphoma

As most parents/patients would probably choose to participate in a surveillance programme, performing a trial would be difficult. The best approach may be to discuss the advantages and disadvantages of surveillance and to make a joint decision (table 7).

A general recommendation is that parents (or adult patients) should contact their doctor if the child (adult patient) develops unusual signs or symptoms. This is especially important in the case of BT, in view of the rather long time to diagnosis.

The programme recommended by the consortium aims to detect the most common cancers. However, a variety of other tumours also occur in CMMR-D (table 2). A prospective randomised trial may be performed to test whether a once yearly (rapid) whole body MRI adds some efficacy to our screening programme.

As already mentioned above, it should be emphasised that the distribution of ages at diagnosis of the various cancers is biased by collection of published cases. In fact, ascertainment bias may be a major issue in all that we know about this condition. As further study is done, less severe cases may possible be seen more frequently.

Nevertheless, the high risk of developing a wide variety of cancers, the high risk of developing multiple cancers, sometimes synchronously, the occurrence of these cancers at a young age and the need for intensive multimodal treatment in the case of cancer, imposes an enormous burden on parents and patients. A recent evaluation of psychological distress in individuals predisposed to develop cancer showed increased levels of distress in adults at risk of developing multiple tumours. ${ }^{64}$ Nothing is known about the psychological distress in patients with CMMR-D and their parents. Therefore, doctors involved in the care of these patients should offer the support of a psychologist. ${ }^{1}$ In addition, the clinical geneticist plays an important role by organising presymptomatic testing of other family members for CMMR-D or LS, and through discussion of the option of prenatal or preimplementation genetic diagnosis.

Individuals at risk for multiple cancers usually see several doctors including paediatric oncologists, neurologists, (neuro) surgeons, gastroenterologists and haematologists. It is important that one of these specialists coordinates the surveillance examinations and is available for the patients if they have questions.

A prerequisite for participation in a surveillance programme is prospective collection of all results of surveillance, including the response to treatment. With this aim in mind, the European consortium established an EU-CMMR-D database. This European registry will allow the (cost)effectiveness of the surveillance programme to be evaluated and will allow the sensitivity of these tumours to chemotherapy to be assessed.

\section{CONCLUSION}

In an era of high-throughput sequencing technologies, an increasing number of patients with CMMR-D are being identified. Most patients die from cancers in early childhood. The only way to improve the prognosis is surveillance for these cancers. Surveillance for CRC, and possibly SBC, might be effective; however, the value of surveillance and early detection of BT and NHL/leukaemia is unknown. The best approach is to discuss the advantages and disadvantages of surveillance. When patients and parents decide to participate, outcomes should be collected and evaluated within the EU registry.

\section{Author affiliations}

${ }^{1}$ Department of Gastroenterology \& Hepatology, Leiden University Medical Centre, Leiden, The Netherlands

${ }^{2}$ Netherlands Foundation for the Detection of Hereditary Tumours, Leiden,

The Netherlands

${ }^{3}$ Department of Pediatric Oncology, Institute Curie, Paris, France

${ }^{4}$ Department of Genetics, Gustave Roussy Cancer Institute, Villejuif, France

${ }^{5}$ Department of Oncogenetics, Gustave Roussy Cancer Institute, Villejuif, France

${ }^{6}$ Inserm, Team 'Microsatellite Instability and Cancer', UMRS 938, Saint-Antoine

Hospital, Paris, France

${ }^{7}$ Department of Pediatric Oncology, University Hospital, Strasbourg, France

${ }^{8}$ Department of Oncology, Sharret Institute, Hadassah Hebrew Medical Centre, Jerusalem, Israe

${ }^{9}$ Department of Pediatrics, Comenius University Medical School, University Children's Hospital, Bratislava, Slovakia

${ }^{10}$ Department of Pediatric Hematology \& Oncology, Hannover Medical School, Hannover, Germany

${ }^{11}$ Department of Pediatrics, Gustave Roussy Cancer Institute, Villejuif, France

${ }^{12}$ Department of Pediatric Hematology \& Oncology, Radboud University Medical Centre, Nijmegen, The Netherlands

${ }^{13}$ Department of Clinical Genetics, VU University Medical Center, Amsterdam, The Netherlands

${ }^{14}$ Department of Dermatology, Gustave Roussy Cancer Institute, Villejuif, France

${ }^{15}$ Department of Genetics, Pitie Salpetriere Hospital, APHP, Paris, France

${ }^{16}$ Department of Pediatric Hematology \& Oncology, University Hospital Munster, Munster, Germany

${ }^{17}$ Division of Human Genetics, Medical University Innsbruck, Innsbruck, Austria

Acknowledgements The authors thank the following colleagues for their contribution during the discussions at the meeting in Paris on 8 June 2013: Felipe Andreiuolo, Centre National de la Recherche Scientifique, Gustave Roussy Cancer Insitute, Villejuif, France; Julie Tinat, Department of Genetics, Faculty of Medicine, University of Rouen, Rouen, France; Marina Dimaria, Department of Genetics, Gustave Roussy Cancer Institute, Villejuif, France; Ada Collura, Basic and translational research, Hospital St Antoine, Paris, France; Cécile Charpy, Department of Pathology, Gustave Roussy Cancer Institue, Villejuif, France; Olivier Buhard, Basic and translational research, Hospital St Antoine, Paris; Sarah Bodo, Basic and translational research, Hospital St Antoine, Paris.

Contributors The guidelines have been discussed during the workshop in Paris. All authors were involved in this discussion. The manuscript was written by HFAV and $Z G$ with specific contributions from KW and $L B$

Competing interests None.

Provenance and peer review Not commissioned; externally peer reviewed. 


\section{REFERENCES}

1 Vasen HF, Blanco I, Aktan-Collan K, Gopie JP, Alonso A, Aretz S, Bernstein I, Bertario L, Burn J, Capella G, Colas C, Engel C, Frayling IM, Genuardi M, Heinimann K, Hes FJ, Hodgson SV, Karagiannis JA, Lalloo F, Lindblom A, Mecklin JP, Moller P, Myrhoj T, Nagengast FM, Parc Y, Ponz de LM, Renkonen-Sinisalo L, Sampson JR, Stormorken A, Sijmons RH, Tejpar S, Thomas HJ Rahner N, Wijnen JT, Jarvinen HJ, Moslein G. Revised guidelines for the clinical management of Lynch syndrome (HNPCC): recommendations by a group of European experts. Gut 2013:62:812-23.

2 Wimmer K, Etzler J. Constitutional mismatch repair-deficiency syndrome: have we so far seen only the tip of an iceberg? Hum Genet 2008;124:105-22.

3 Jarvinen HJ, Aarnio M, Mustonen H, Aktan-Collan K, Aaltonen LA, Peltomaki P, de la CA, Mecklin JP. Controlled 15-year trial on screening for colorectal cancer in families with hereditary nonpolyposis colorectal cancer. Gastroenterology 2000;118:829-34.

4 Durno CA, Aronson M, Tabori U, Malkin D, Gallinger S, Chan HS. Oncologic surveillance for subjects with biallelic mismatch repair gene mutations: 10 year follow-up of a kindred. Pediatr Blood Cancer 2012:59:652-6.

5 Sjursen W, Bjornevoll I, Engebretsen LF, Fjelland K, Halvorsen T, Myrvold HE. A homozygote splice site PMS2 mutation as cause of Turcot syndrome gives rise to two different abnormal transcripts. Fam Cancer 2009;8:179-86.

6 Wilson JM, Jungner YG. [Principles and practice of mass screening for disease]. Bol Oficina Sanit Panam 1968:65:281-393.

7 Song KS, Phi JH, Cho BK, Wang KC, Lee JY, Kim DG, Kim IH, Ahn HS, Park SH, Kim SK. Long-term outcomes in children with glioblastoma. J Neurosurg Pediatr 2010;6:145-9

8 Perkins SM, Rubin JB, Leonard JR, Smyth MD, El NI, Michalski JM, Simpson JR, Limbrick DL, Park TS, Mansur DB. Glioblastoma in children: a single-institution experience. Int J Radiat Oncol Biol Phys 2011;80:1117-21.

9 Brasme JF, Morfouace M, Grill J, Martinot A, Amalberti R, Bons-Letouzey C, Chalumeau M. Delays in diagnosis of paediatric cancers: a systematic review and comparison with expert testimony in lawsuits. Lancet Oncol 2012;13:e445-59.

10 Durno CA, Holter S, Sherman PM, Gallinger S. The gastrointestinal phenotype of germline biallelic mismatch repair gene mutations. Am J Gastroenterol 2010;105:2449-56

11 Herkert JC, Niessen RC, Olderode-Berends MJ, Veenstra-Knol HE, Vos YJ, van de Klift HM, Scheenstra R, Tops CM, Karrenbeld A, Peters FT, Hofstra RM, Kleibeuker JH, Sijmons RH. Paediatric intestinal cancer and polyposis due to bi-allelic PMS2 mutations: case series, review and follow-up guidelines. Eur J Cancer 2011:47:965-82.

12 Rodriguez-Bigas MA, Vasen HF, Lynch HT, Watson P, Myrhoj T, Jarvinen HJ, Mecklin JP, Macrae F, St John DJ, Bertario L, Fidalgo P, Madlensky L, Rozen P. Characteristics of small bowel carcinoma in hereditary nonpolyposis colorectal carcinoma. International Collaborative Group on HNPCC. Cancer 1998;83:240-4.

13 Zaanan A, Costes L, Gauthier M, Malka D, Locher C, Mitry E, Tougeron D, Lecomte T, Gornet JM, Sobhani I, Moulin V, Afchain P, Taieb J, Bonnetain F, Aparicio T. Chemotherapy of advanced small-bowel adenocarcinoma: a multicenter AGEO study. Ann Oncol 2010;21:1786-93.

14 Burkhardt B, Zimmermann M, Oschlies I, Niggli F, Mann G, Parwaresch R, Riehm H, Schrappe $M$, Reiter $A$. The impact of age and gender on biology, clinical features and treatment outcome of non-Hodgkin lymphoma in childhood and adolescence. Br J Haematol 2005;131:39-49.

15 Rondagh EJ, Gulikers S, Gomez-Garcia EB, Vanlingen Y, Detisch Y, Winkens B, Vasen HF, Masclee AA, Sanduleanu S. Nonpolypoid colorectal neoplasms: a challenge in endoscopic surveillance of patients with Lynch syndrome. Endoscopy 2013:45:257-64.

16 Haanstra JF, Vasen HF, Sanduleanu S, van der Wouden EJ, Koornstra JJ, Kleibeuker JH, de Vos tot Nederveen Cappel WH. Quality colonoscopy and risk of interval cancer in Lynch syndrome. Int J Colorectal Dis 2013.

17 Saurin JC, Pilleul F, Soussan EB, Maniere T, D'Halluin PN, Gaudric M, Cellier C, Heresbach D, Gaudin JL. Small-bowel capsule endoscopy diagnoses early and advanced neoplasms in asymptomatic patients with Lynch syndrome. Endoscopy 2010:42:1057-62.

18 Fedier A, Fink D. Mutations in DNA mismatch repair genes: implications for DNA damage signaling and drug sensitivity (review). Int J Oncol 2004;24:1039-47.

19 Jiricny J. The multifaceted mismatch-repair system. Nat Rev Mol Cell Biol 2006;7:335-46.

20 Devaud N, Gallinger S. Chemotherapy of MMR-deficient colorectal cancer. Fam Cancer 2013:12:301-6.

21 Ribic CM, Sargent DJ, Moore MJ, Thibodeau SN, French AJ, Goldberg RM, Hamilton SR, Laurent-Puig P, Gryfe R, Shepherd LE, Tu D, Redston M, Gallinger S. Tumor microsatellite-instability status as a predictor of benefit from fluorouracil-based adjuvant chemotherapy for colon cancer. N Engl J Med 2003;349:247-57.

22 Sargent DJ, Marsoni S, Monges G, Thibodeau SN, Labianca R, Hamilton SR, French AJ, Kabat B, Foster NR, Torri V, Ribic C, Grothey A, Moore M, Zaniboni A Seitz JF, Sinicrope F, Gallinger $S$. Defective mismatch repair as a predictive marker for lack of efficacy of fluorouracil-based adjuvant therapy in colon cancer. J Clin Oncol 2010;28:3219-26.

23 Meyers M, Wagner MW, Hwang HS, Kinsella TJ, Boothman DA. Role of the hMLH1 DNA mismatch repair protein in fluoropyrimidine-mediated cell death and cell cycle responses. Cancer Res 2001;61:5193-201.

24 Dorard C, de TA, Collura A, Marisa L, Svrcek M, Lagrange A, Jego G, Wanherdrick K, Joly AL, Buhard O, Gobbo J, Penard-Lacronique V, Zouali H, Tubacher E, Kirzin S, Selves J, Milano G, Etienne-Grimaldi MC, Bengrine-Lefevre L, Louvet C, Tournigand C, Lefevre JH, Parc Y, Tiret E, Flejou JF, Gaub MP, Garrido C, Duval A. Expression of a mutant HSP110 sensitizes colorectal cancer cells to chemotherapy and improves disease prognosis. Nat Med 2011;17:1283-9.

25 Nehme A, Baskaran R, Aebi S, Fink D, Nebel S, Cenni B, Wang JY, Howell SB, Christen RD. Differential induction of c-Jun NH2-terminal kinase and c-Abl kinase in DNA mismatch repair-proficient and -deficient cells exposed to cisplatin. Cancer Res 1997; 57:3253-7.

26 Fink $D$, Zheng $H$, Nebel S, Norris PS, Aebi S, Lin TP, Nehme A, Christen RD, Haas M, MacLeod CL, Howell SB. In vitro and in vivo resistance to cisplatin in cells that have lost DNA mismatch repair. Cancer Res 1997;57:1841-5.

27 Des GG, Mariani P, Cucherousset J, Benamoun M, Lagorce C, Sastre X, Le TP, Uzzan B, Perret GY, Morere JF, Breau JL, Fagard R, Schischmanoff PO. Microsatellite instability and sensitivitiy to FOLFOX treatment in metastatic colorectal cancer. Anticancer Res 2007;27(4C):2715-19.

28 Kim ST, Lee J, Park SH, Park JO, Lim HY, Kang WK, Kim JY, Kim YH, Chang DK, Rhee PL, Kim DS, Yun H, Cho YB, Kim HC, Yun SH, Chun HK, Lee WY, Park YS. The effect of DNA mismatch repair (MMR) status on oxalaplatin-based first-line chemotherapy as in recurrent or metastatic colon cancer. Med Oncol 2010;27:1277-85.

29 Jacob S, Aguado M, Fallik D, Praz F. The role of the DNA mismatch repair system in the cytotoxicity of the topoisomerase inhibitors camptothecin and etoposide to human colorectal cancer cells. Cancer Res 2001:61:6555-62.

30 Magrini R, Bhonde MR, Hanski ML, Notter M, Scherubl H, Boland CR, Zeitz M, Hanski C. Cellular effects of CPT-11 on colon carcinoma cells: dependence on p53 and hMLH1 status. Int J Cancer 2002;101:23-31.

31 Charara M, Edmonston TB, Burkholder S, Walters R, Anne P, Mitchell E, Fry R, Boman B, Rose D, Fishel R, Curran W, Palazzo J. Microsatellite status and cell cycle associated markers in rectal cancer patients undergoing a combined regimen of 5-FU and CPT-11 chemotherapy and radiotherapy. Anticancer Res 2004;24 (5B):3161-7.

32 Fallik D, Borrini F, Boige V, Viguier J, Jacob S, Miquel C, Sabourin JC, Ducreux M Praz F. Microsatellite instability is a predictive factor of the tumor response to irinotecan in patients with advanced colorectal cancer. Cancer Res 2003;63:5738-44.

33 Martin SA, McCarthy A, Barber LJ, Burgess DJ, Parry S, Lord CJ, Ashworth A Methotrexate induces oxidative DNA damage and is selectively lethal to tumour cells with defects in the DNA mismatch repair gene MSH2. EMBO Mol Med 2009;1:323-37.

34 Gallinger S, Aronson M, Shayan K, Ratcliffe EM, Gerstle JT, Parkin PC, Rothenmund $H$, Croitoru M, Baumann E, Durie PR, Weksberg R, Pollett A Riddell RH, Ngan BY, Cutz E, Lagarde AE, Chan HS. Gastrointestinal cancers and neurofibromatosis type 1 features in children with a germline homozygous MLH1 mutation. Gastroenterology 2004;126:576-85.

35 Gururangan S, Frankel W, Broaddus R, Clendenning M, Senter L, McDonald M, Eastwood J, Reardon D, Vredenburgh J, Quinn J, Friedman HS. Multifocal anaplastic astrocytoma in a patient with hereditary colorectal cancer, transcobalamin II deficiency, agenesis of the corpus callosum, mental retardation, and inherited PMS2 mutation. Neuro Oncol 2008;10:93-7.

36 Tan TY, Orme LM, Lynch E, Croxford MA, Dow C, Dewan PA, Lipton L. Biallelic PMS2 mutations and a distinctive childhood cancer syndrome. J Pediatr Hematol Oncol 2008:30:254-7.

37 Jackson CC, Holter S, Pollett A, Clendenning M, Chou S, Senter L, Ramphal R, Gallinger S, Boycott K. Cafe-au-lait macules and pediatric malignancy caused by biallelic mutations in the DNA mismatch repair (MMR) gene PMS2. Pediatr Blood Cancer 2008:50:1268-70.

38 Kruger S, Kinzel M, Walldorf C, Gottschling S, Bier A, Tinschert S, von SA, Henn W, Gorgens H, Boue S, Kolble K, Buttner R, Schackert HK. Homozygous PMS2 germline mutations in two families with early-onset haematological malignancy, brain tumours, HNPCC-associated tumours, and signs of neurofibromatosis type 1. Eur $J$ Hum Genet 2008; 16:62-72.

39 Rahner N, Hoefler G, Hogenauer C, Lackner C, Steinke V, Sengteller M, Friedl W, Aretz S, Propping P, Mangold E, Walldorf C. Compound heterozygosity for two MSH6 mutations in a patient with early onset colorectal cancer, vitiligo and systemic lupus erythematosus. Am J Med Genet A 2008:146A:1314-19.

40 Kratz CP, Holter S, Etzler J, Lauten M, Pollett A, Niemeyer CM, Gallinger S, Wimmer K. Rhabdomyosarcoma in patients with constitutional mismatch-repair-deficiency syndrome. J Med Genet 2009;46:418-20.

41 Toledano H, Goldberg Y, Kedar-Barnes I, Baris H, Porat RM, Shochat C, Bercovich D, Pikarsky E, Lerer I, Yaniv I, Abeliovich D, Peretz T. Homozygosity of 
MSH2 c.1906G-->C germline mutation is associated with childhood colon cancer, astrocytoma and signs of Neurofibromatosis type I. Fam Cancer 2009;8:187-94.

42 Vasovcak P, Krepelova A, Menigatti M, Puchmajerova A, Skapa P, Augustinakova A Amann $G$, Wernstedt $A$, Jiricny J, Marra $G$, Wimmer K. Unique mutational profile associated with a loss of TDG expression in the rectal cancer of a patient with a constitutional PMS2 deficiency. DNA Repair (Amst) 2012;11:616-23.

43 Lindsay H, Jubran RF, Wang L, Kipp BR, May WA. Simultaneous Colonic Adenocarcinoma and Medulloblastoma in a 12-Year-Old with Biallelic Deletions in PMS2. J Pediatr 2013;163:601-3.

44 Scott RH, Mansour S, Pritchard-Jones K, Kumar D, MacSweeney F, Rahman N. Medulloblastoma, acute myelocytic leukemia and colonic carcinomas in a child with biallelic MSH6 mutations. Nat Clin Pract Oncol 2007;4:130-4.

45 Hunter C, Smith R, Cahill DP, Stephens P, Stevens C, Teague J, Greenman C, Edkins $S$, Bignell G, Davies H, O'Meara S, Parker A, Avis T, Barthorpe $S$, Brackenbury L, Buck G, Butler A, Clements J, Cole J, Dicks E, Forbes S, Gorton M, Gray K, Halliday K, Harrison R, Hills K, Hinton J, Jenkinson A, Jones D, Kosmidou V, Laman R, Lugg R, Menzies A, Perry J, Petty R, Raine K, Richardson D, Shepherd R, Small A, Solomon H, Tofts C, Varian J, West S, Widaa S, Yates A, Easton DF, Riggins G, Roy JE, Levine KK, Mueller W, Batchelor TT, Louis DN, Stratton MR, Futreal PA, Wooster R. A hypermutation phenotype and somatic MSH6 mutations in recurrent human malignant gliomas after alkylator chemotherapy. Cancer Res 2006:66:3987-91.

46 Offman J, Opelz G, Doehler B, Cummins D, Halil O, Banner NR, Burke MM, Sullivan D, Macpherson P, Karran P. Defective DNA mismatch repair in acute myeloid leukemia/ myelodysplastic syndrome after organ transplantation. Blood 2004:104:822-8.

47 Fink D, Nebel S, Norris PS, Baergen RN, Wilczynski SP, Costa MJ, Haas M, Cannistra SA, Howell SB. Enrichment for DNA mismatch repair-deficient cells during treatment with cisplatin. Int J Cancer 1998;77:741-6.

48 Chalastanis A, Penard-Lacronique V, Surcek M, Defaweux V, Antoine N, Buhard O, Dumont S, Fabiani B, Renault I, Tubacher E, Flejou JF, Te RH, Duval A, Muleris M. Azathioprine-induced carcinogenesis in mice according to Msh2 genotype. J Natl Cancer Inst 2010;102:1731-40.

49 Duval A, Raphael M, Brennetot C, Poirel H, Buhard O, Aubry A, Martin A, Krimi A, Leblond V, Gabarre J, Davi F, Charlotte F, Berger F, Gaidano G, Capello D, Canioni D, Bordessoule D, Feuillard J, Gaulard P, Delfau MH, Ferlicot S, Eclache V, Prevot S, Guettier C, Lefevre PC, Adotti F, Hamelin R. The mutator pathway is a feature of immunodeficiency-related lymphomas. Proc Natl Acad Sci USA 2004;101:5002-7.

50 Mao G, Yuan F, Absher K, Jennings CD, Howard DS, Jordan CT, Gu L. Preferential loss of mismatch repair function in refractory and relapsed acute myeloid leukemia: potential contribution to AML progression. Cell Res 2008;18:281-9.

51 Borie C, Colas C, Dartigues $P$, Lazure T, Rince $P$, Buhard O, Folliot $P$, Chalastanis A, Muleris M, Hamelin R, Mercier D, Oliveira C, Seruca R, Chadburn A, Leblond V, Barete S, Gaidano G, Martin A, Gaulard P, Flejou JF, Raphael M, Duval A. The mechanisms underlying MMR deficiency in immunodeficiency-related non-Hodgkin lymphomas are different from those in other sporadic microsatellite instable neoplasms. Int I Cancer 2009;125:2360-6.
52 Ilencikova D, Sejnova D, Jindrova J, Babal P. High-grade brain tumors in siblings with biallelic MSH6 mutations. Pediatr Blood Cancer 2011;57:1067-70.

53 Cahill DP, Levine KK, Betensky RA, Codd PJ, Romany CA, Reavie LB, Batchelor TT, Futreal PA, Stratton MR, Curry WT, lafrate AJ, Louis DN. Loss of the mismatch repair protein MSH6 in human glioblastomas is associated with tumor progression during temozolomide treatment. Clin Cancer Res 2007;13:2038-45.

54 Menko FH, Kaspers GL, Meijer GA, Claes K, van Hagen JM, Gille JJ. A homozygous MSH6 mutation in a child with cafe-au-lait spots, oligodendroglioma and rectal cancer. Fam Cancer 2004;3:123-7.

55 Etzler J, Peyrl A, Zatkova A, Schildhaus HU, Ficek A, Merkelbach-Bruse S, Kratz CP, Attarbaschi A, Hainfellner JA, Yao S, Messiaen L, Slavc I, Wimmer K. RNA-based mutation analysis identifies an unusual MSH6 splicing defect and circumvents PMS2 pseudogene interference. Hum Mutat 2008;29:299-305.

56 Johannesma PC, van der Klift HM, Van Grieken NC, Troost D, Te RH, Jacobs MA, Postma TJ, Heideman DA, Tops CM, Wijnen JT, Menko FH. Childhood brain tumours due to germline bi-allelic mismatch repair gene mutations. Clin Genet 2011;80:243-55.

57 Baas AF, Gabbett M, Rimac M, Kansikas M, Raphael M, Nievelstein RA, Nicholls W, Offerhaus J, Bodmer D, Wernstedt A, Krabichler B, Strasser U, Nystrom M, Zschocke J, Robertson SP, van Haelst MM, Wimmer K. Agenesis of the corpus callosum and gray matter heterotopia in three patients with constitutional mismatch repair deficiency syndrome. Eur J Hum Genet 2013;21:55-61.

58 Yeung JT, Pollack IF, Shah S, Jaffe R, Nikiforova M, Jakacki RI. Optic pathway glioma as part of a constitutional mismatch-repair deficiency syndrome in a patient meeting the criteria for neurofibromatosis type 1. Pediatr Blood Cancer 2013;60: $137-9$

59 Ostergaard JR, Sunde L, Okkels H. Neurofibromatosis von Recklinghausen type phenotype and early onset of cancers in siblings compound heterozygous for mutations in MSH6. Am J Med Genet A 2005;139A:96-105.

60 Scott RH, Homfray T, Huxter NL, Mitton SG, Nash R, Potter MN, Lancaster D, Rahman N. Familial T-cell non-Hodgkin lymphoma caused by biallelic MSH2 mutations. J Med Genet 2007:44:e83.

61 Kratz CP, Niemeyer CM, Juttner E, Kartal M, Weninger A, Schmitt-Graeff $A$, Kontny U, Lauten M, Utzolino S, Radecke J, Fonatsch C, Wimmer K. Childhood T-cell non-Hodgkin's lymphoma, colorectal carcinoma and brain tumor in association with cafe-au-lait spots caused by a novel homozygous PMS2 mutation. Leukemia 2008;22:1078-80.

62 Peters $A$, Born $H$, Ettinger R, Levonian $P$, Jedele KB. Compound heterozygosity for MSH6 mutations in a pediatric lymphoma patient. I Pediatr Hematol Oncol 2009;31:113-15.

63 Ripperger T, Beger C, Rahner N, Sykora KW, Bockmeyer CL, Lehmann U, Kreipe HH, Schlegelberger B. Constitutional mismatch repair deficiency and childhood leukemia/ lymphoma—report on a novel biallelic MSH6 mutation. Haematologica 2010;95:841-4.

64 Gopie JP, Vasen HF, Tibben A. Surveillance for hereditary cancer: does the benefit outweigh the psychological burden?-A systematic review. Crit Rev Oncol Hematol 2012;83:329-40. 